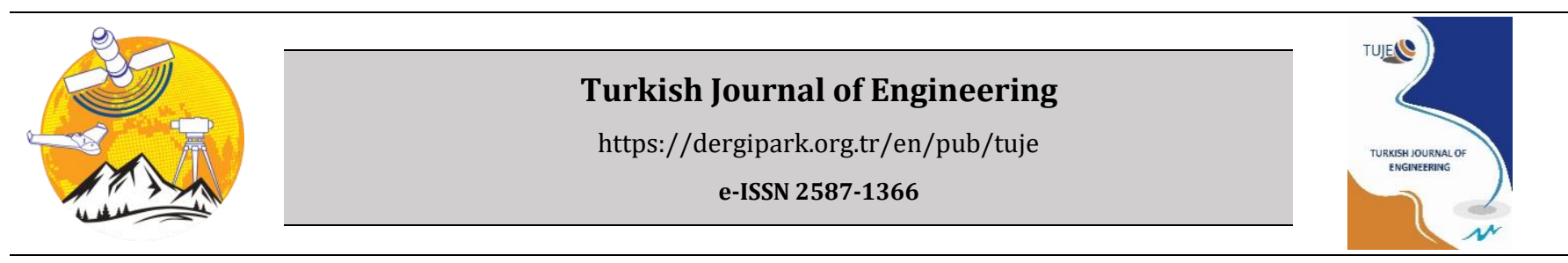

\title{
Comparison of experimental and numerical analysis of Quasi-Static punch shear test for stainless steel sheet material
}

\author{
Mehmet Şahbaz*1] \\ ${ }^{1}$ Karamanoğlu Mehmetbey University, Faculty of Engineering, Mechanical Engineering Department, Karaman, Turkey
}

\author{
Keywords \\ Sheet Metal \\ Finite Element Analysis \\ Punch Test
}

\begin{abstract}
In this study, Quasi-Static Punch Shear Test (QS-PST) for AISI-304 stainless steel sheet material with $0.5 \mathrm{~mm}$ thickness was performed experimentally and numerically, then the results were compared. QS-PST was designed non-standard according to the need and is especially used to determine the puncture resistance of composite plate materials against lowspeed loading. Since the results obtained from QS-PST are similar to those from ballistic tests, this has attracted the attention of researchers. The experimental study was carried out by integrating the die and punch which were specially produced for this test, into an electromechanical tensile-compression test device with a capacity of $100 \mathrm{kN}$. In order to define the material properties correctly in numerical analysis, the tensile tests of the relevant material were also carried out with the same device. Then, the CAD model of the experimental system was generated and Finite Element Analysis (FEA) was performed. In FEA, the mesh structure was determined as tetrahedral, since it gave closer results in such tests and the analyzes were performed by increasing the number of mesh from 16700 to 151800 elements. Finally, the experimentally and numerically obtained results were compared and it was observed that the result were very close depending on increasing the number of mesh.
\end{abstract}

\section{INTRODUCTION}

Sheet metal materials are most widely used material type in almost all industrial fields, from automotive to aeronautics, from food to agriculture (Aydın and Karaağaç 2019). These materials are exposed to external factors that negatively affect their lifetime, depending on the environment and conditions in which they are used. Or, they may lose their integrity by being subject to deformation in the face of uncalculated loadings, or they may lose their function by being deformed. In order to prevent such situations, manufacturers develop material production processes and apply different methods to make sheet materials more resistant to such undesirable situations. For example, galvanization or alloying processes applied for providing corrosion resistance in areas where corrosion is not desired. Similarly, types of stainless steel made with chromium-nickel reinforcement are widely used in mechanical engineering due to their high mechanical properties, chemical resistance to corrosion, and low costs. (Kaoumi and Liu 2018).

Along with technological developments, stainless steels are used in many sectors such as chemical and automotive industries, electronic devices, medical applications. Stainless steels are used as components in many applications due to their high tensile strength and ability to work at high temperatures. (Al-Bakri et al. 2016). Moreover, stainless steels are frequently preferred in food industry because of their high corrosion resistance properties (Çeliker et al., 2021).

Stainless steels are categorized according to their crystal phase and microstructure. According to this classification, they are named as; austenitic stainless steels (300 series), ferritic stainless steels (430, 442 etc.), martensitic stainless steels $(403,410,420$ etc.), and duplex (Ferritic-Austenitic) stainless steels (1.4362, 1.4507 etc.) (Türkoğlu and Ay 2021). After giving brief 
information about sheet metals, especially stainless steels, some of the scientific studies in this field are briefly summarized. Köleoğlu et al., investigated the effects of plasticity models in their study, which model the plastic behavior of materials in sheet metal forming processes on finite element estimation. For this purpose, they examined different plasticity models in terms of both deformation and tearing (Köleoğlu et al. 2019). In a similar study, Vatansever and Esener analyzed the effects of calculation parameters on simulation precision and solution time with FEA of sheet metal forming. In particular, they determined the parameters that minimize the solution time and improved the solution time (Vatansever and Esener 2019).

Karajibani et al., on the other hand, presented a simulation-based approach for the determination of the forming layer curve (FLC) in bilayer metal sheets. In this study, they obtained the FLC of aluminum-1100 / copper-C10100 two-layer plate through numerical analysis and experimental research (Karajibani et al. 2017). In another study, Çağdaş and Taşkın, 2020. developed a modified analytical expression to determine the quasi-static pre-indentation loads of foam core sandwich beams with thin laminated galvanized steel surfaces, which may be valuable in the preliminary design phase. This analytical statement was confirmed by the indentation tests, and they also examined the effects of the surface layer lamination parameters on the indentation (Çăgdaş and Taşkın 2020).

When the studies were examined, it was observed that there were intensive and different studies on sheet materials, and it was observed that both experimental and numerical studies were carried out. The produced sheet materials are tested, especially for chemical and mechanical resistance and whether they are suitable for the area of use during the production phase. Most frequently preferred mechanical tests for sheet materials are: tensile, three-point bending and hardness tests. However, tests for measuring the shear resistance of the material against puncture are not widely used on the surface of highly loaded impacts concentrated in small areas that can be considered as points. One of the most popular tests in this field is QS-PST, which is used to determine the puncture resistance of sheet materials due to its similarity with ballistic results (Kawano et al. 1988; Longère and Dragon 2015). In addition, in recent years, experimental and numerical applications of QS-PST have been increasing in composite materials, which have replaced metals due to their light weight and high strength properties. (Ayten et al. 2020; Salman et al. 2018). Although the QS-PST looks similar to punching, which is a mechanical forming method, it is a different test method as it tests material resistance using different pitch-to-punch ratios (SPR) and different punch tip geometries (flat, conical, and pyramidal). In addition, this test gives a preview of how sheet metal materials will behave during the press-forming process. Sheet materials are commonly converted into products by printing-forming methods (Karajibani et al. 2017; Șener et al. 2020; Vatansever \& Esener 2019). It is thought that the experimental and numerical application of QS-PST to the material will be beneficial in overcoming the production problems encountered in this process.
When the literature is examined, although there are similar studies, however neither numerical nor experimental application of QS-PST for stainless steels has been found. For this reason, even though this study is new in this field, it is thought that it will contribute to the literature. Thus, it was aimed to apply this method, which is frequently used in the testing of composite materials, to metal materials.

In this study, a non-standard QS-PST was applied to stainless steel sheet material experimentally and numerically, and the results were compared. Thus, the generated CAD model and system were verified. In order to determine the most accurate model, FEAs were repeated by reducing the mesh size and increasing the number of elements. It has been observed that when the number of elements is increased, the results of the FEAs approached to the experimental study results. Consequently, the importance of mesh size and number in numerical analysis has been demonstrated. This method is frequently used in the literature for the validation of numerical analysis models (Uçtu et al. 2017; Seyedzavvar et al. 2022). In addition, the same material was subjected to tensile tests with two different strain rates to identify the material in the library of the numerical analysis software.

\section{METHOD}

AISI-304 stainless steel (304 SS) sheet metal with a thickness of $0.5 \mathrm{~mm}$ was chosen as the test material. This material was cut with a liquid-cooled cutting device in suitable sizes for QS-PST with edge lengths of $100 \times 100$ $\mathrm{mm}$ thus, the workpiece was made ready for the test. 304 $\mathrm{SS}$ has $8.00 \mathrm{~g} / \mathrm{cm}^{3}$ density, $193 \mathrm{GPa}$ modulus of elasticity, 540 - $750 \mathrm{MPa}$ tensile strength, and elongation $45 \%$. It also includes nearly $18 \%$ chromium and $8 \%$ nickel elements.

The QS-PST die consists of three parts, the lower die consists of two parts, and the punch is included as the third part. (Fig. 1). In this study, the punch tip geometry was selected as straight cylinder for both experimental and numerical investigations, and the span-to-punch ratio (SPR) ratio was specified as 2 . Moreover, while the punch diameter is $13 \mathrm{~mm}$, the gap diameter corresponds to $26 \mathrm{~mm}$. This die was specially designed for the electromechanical tensile-compression tester, and is made of special hardened steel. Thus, it can resist to deflection and deformation.

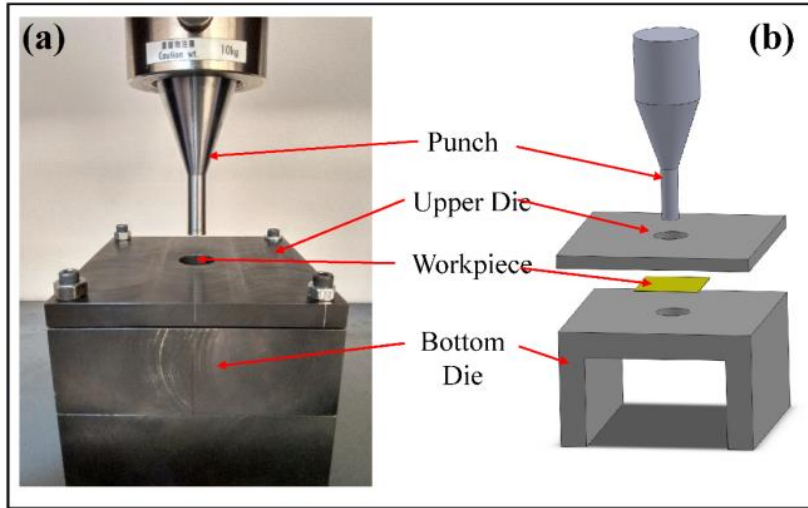

Figure 1. QS-PST system (a) experimental setup, (b) CAD model 
In Fig. 1, the experimental setup and the CAD model of this setup can be seen. In order to shorten the solution time of FEA by reducing the number of meshes in the CAD model, the dimensions of the workpiece were reduced by $50 \%$ (to $50 \times 50 \mathrm{~mm}$ ).

As a method, first of all, the experimental setup was prepared and the QS-PST application was made. The prepared workpiece was firstly subjected to punch tests in the experimental setup. The feed rate of the punch was kept constant as $2 \mathrm{~mm} / \mathrm{d}$ in all experiments

Later on, the CAD model of the material was prepared and made ready for numerical analysis. In order to investigate the plastic deformation three-dimensional FEAs were performed by using Deform 3D software. This software is widely preferred for numerical modeling of machining methods (Hasçelik and Aslantaş 2021). Also this software is frequently preferred in severe plastic deformation studies with its realistic results (Ögüt et al. 2021; Şahbaz et al. 2019). For this reason, it was chosen in this study as well. In all analyzes, the temperature was selected as $20{ }^{\circ} \mathrm{C}$ and the coefficient of friction was specified as 0.08 in shear mode. In addition, in order to make the behavior of the material more accurate and reliable in numerical analysis, the tensile tests were performed on the same material and it was identified as a new material in the material library of the FEA software.

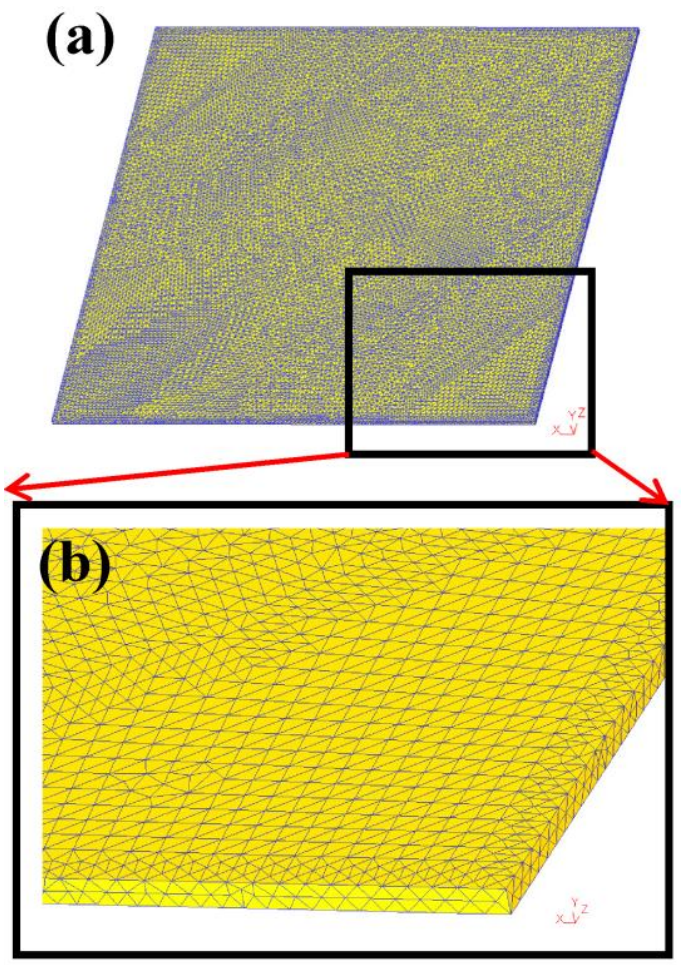

Figure 2. (a) Fine-mesh representation of the workpiece (b) detailed representation of the double-layer mesh

The mentioned tensile tests were repetitive, and tensile rates were adjusted to correspond to material strain rates of $0.25 \mathrm{sec}^{-1}$ and $8 \mathrm{sec}^{-1}$. In the tensile tests, the length of the tensile specimen was at least 5 times larger than the width, taking into account the ASTM-E8 standards. The tensile tests applied to specimens with 70 $\mathrm{mm}$ gauge length, $12.5 \mathrm{~mm}$ width, and $0,5 \mathrm{~mm}$ thickness. Then, the prepared CAD model was defined to the FEA software and the finite element mesh structure of the workpiece was prepared. It is very important to determine the number of mesh as accurately as possible so that the results of the analysis give absolute accuracy and similarity with the experimental results. For this reason, without changing the geometry of the workpiece and other parameters, the number of mesh was gradually increased from 16700 to 151800 , and 7 analyzes were performed. Finally, since the result of the analysis with the mesh number of 151800 is closest to the experimental result, it was decided that it would be more accurate to examine the outputs of this analysis in numerical results. Before the numerical analysis, the workpiece consists of a very fine finite element mesh as shown in Fig. 2 and consists of 151800 tetrahedral elements and 39433 nodes. In this type of deformation analysis, the tetrahedral mesh structure is preferred because it requires the least user interaction and supports adaptive mesh thinning, and accordingly gives more accurate results. The union of these small regions, called finite elements, is called a finite element mesh. Elements that make up the finite element network are connected to each other by nodes located on the edges of the elements (Emirler et al. 2019; Şahbaz et al. 2013; Şahbaz et al. 2016). In the numerical analysis, the punch speed was applied as $2 \mathrm{~mm} / \mathrm{d}$, same as the experiments.

\section{RESULTS and DISCUSSION}

As a result of this experimental study, it was observed how the sheet material was deformed by the QS-PST effect. In this process, the changes in the force according to the punch progress were recorded thanks to the software of the test device.

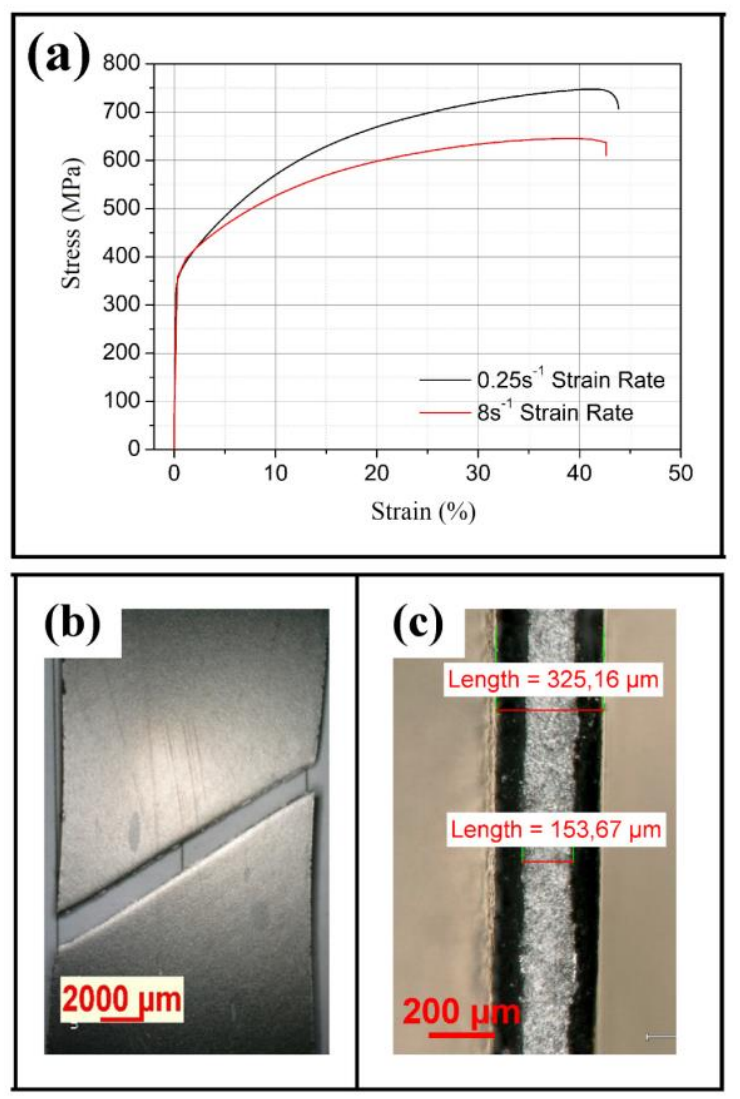

Figure 3. Tensile results at different speeds (a) StressStrain graph, (b) angular tensile fracture, (c) fracture surface 
The shear stress was calculated by using the simple shear equation $(\tau=F / A)$ with the data obtained from this software. Here, ' $\tau$ ' is the shear stress, its unit is $M P a$, ' $F$ ' is the total force on the punch, its unit is Newton, and 'A' is the area subjected to shear, which is the product of the circumference of the circle that the punch contacts with the material thickness, its unit is $\mathrm{mm}^{2}$. For this study, since the punch circle circumference $(\pi \mathrm{d})$ is $40.84 \mathrm{~mm}$ and the material thickness is $0.5 \mathrm{~mm}$, the cutting area ' $\mathrm{A}$ ' corresponds to $20.42 \mathrm{~mm}^{2}$.

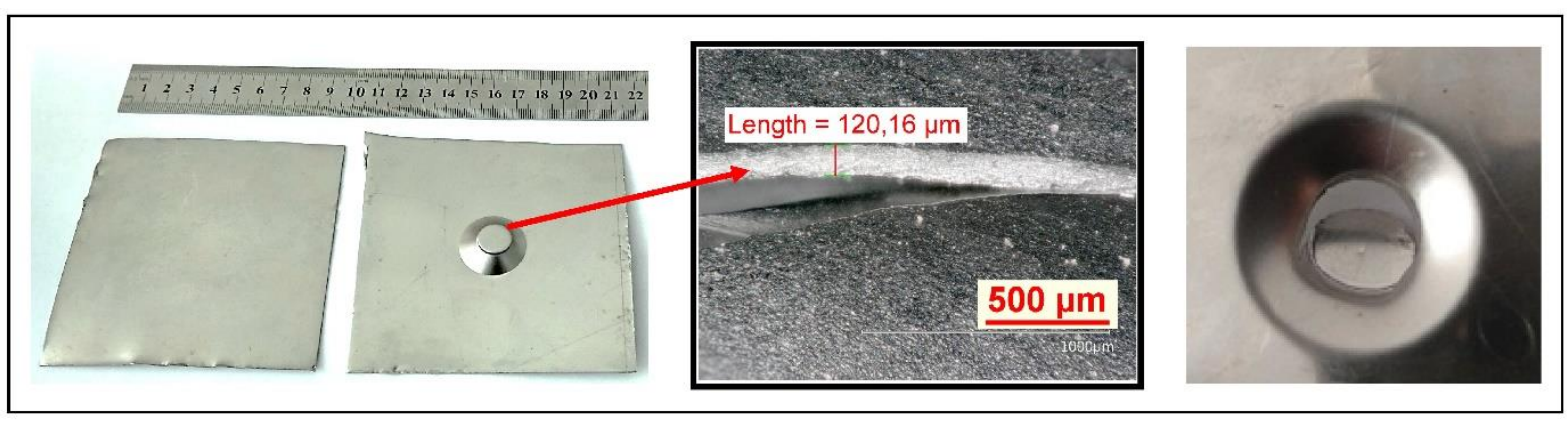

Figure 4. Material view before and after QS-PST

(a)

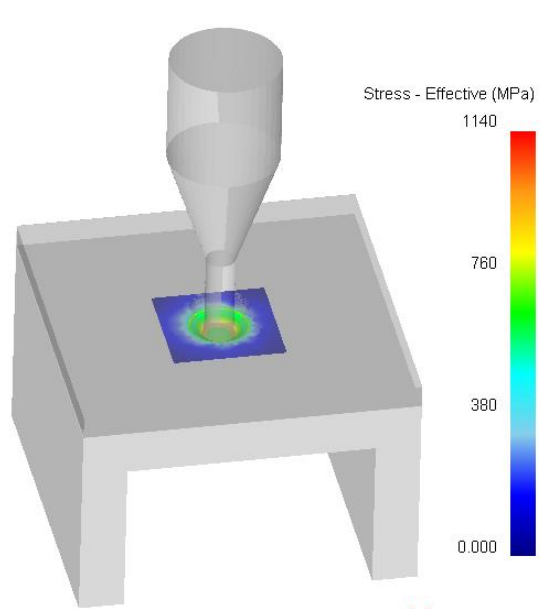

(c)

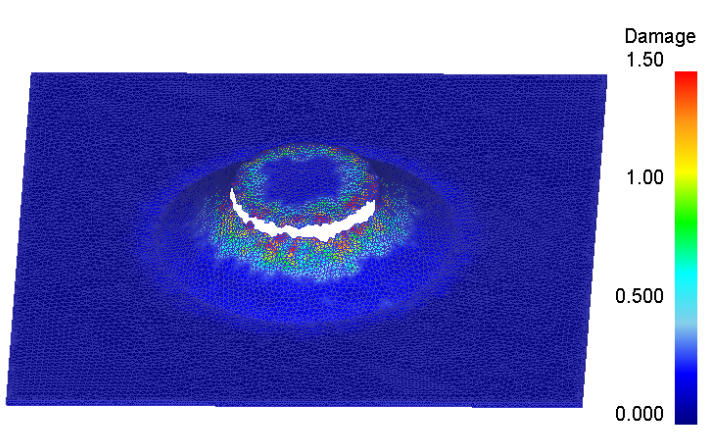

(e)

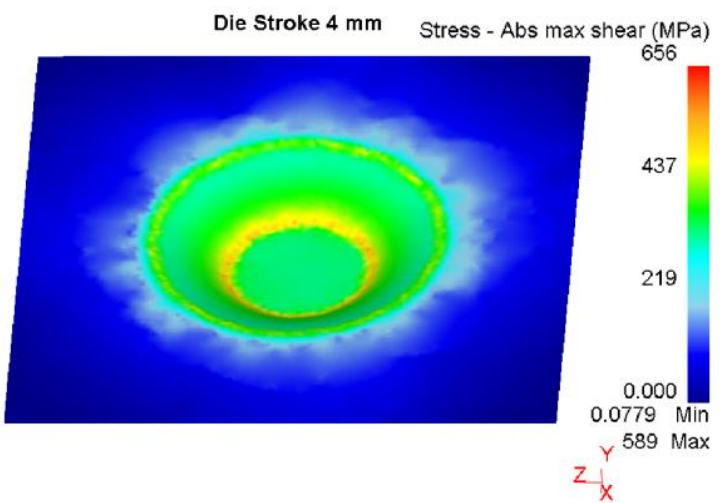

(b)

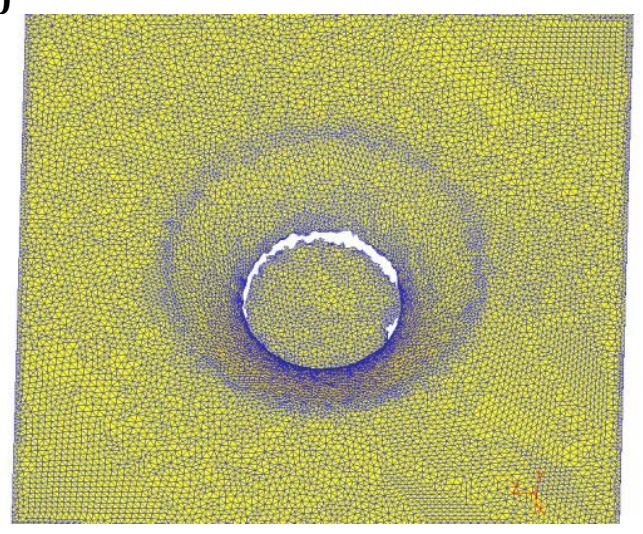

(d)

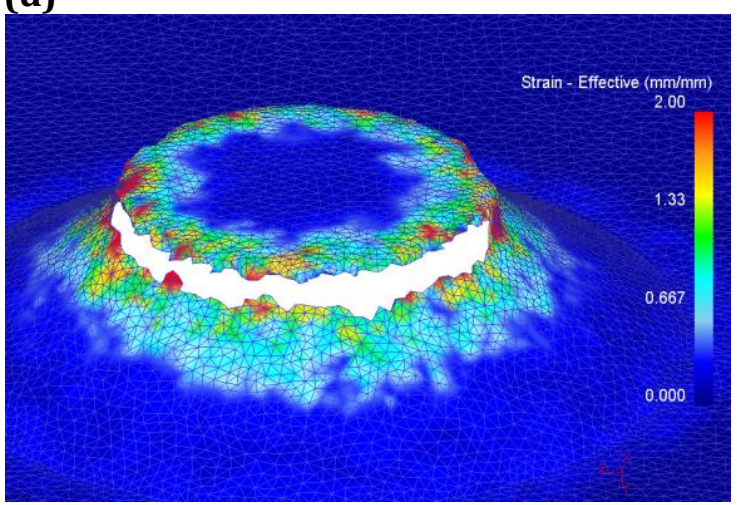

(f)

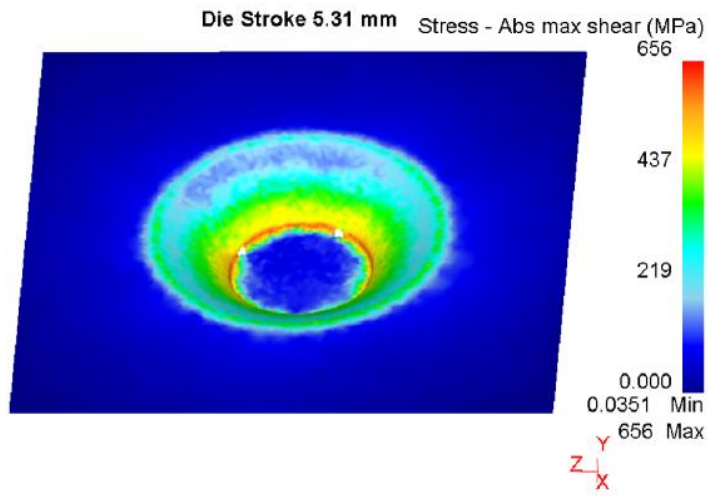

Figure 5. Numerical analysis result (a) test system, (b-e) workpiece stress, strain and damage results and views 
Because of the material has a high formability feature, a high rate of deformation is observed until crack and separation formations as seen in figures (Fig. 3-4). In order to better analyze these properties, the tensile tests performed, and it was observed that the elongation of the material was around 45\% (Fig. 3a). This result was confirmed by similar results in the literature review (Kaoumi \& Liu 2018). In addition, it was observed that increasing the strain rate in the tensile test did not affect the deformation excessively, but decreased the maximum stress value (Fig. 3a). As a result of the tensile test, the material was broken with an angle from the planes with the maximum shear stress (Fig. 3b), the optical microscope view of the fractured surface and the measurement of the thickness decrease during fracture are shown in Fig. 3c.

Fig. 4 shows the workpiece before and after the experimental QS-PST, a close-up view of the deformation area and a microscope view of the separation surface. When the thinning rate of the surfaces after fracture was measured with the aid of a digital optical microscope, it was determined that the material thickness, which was $0.5 \mathrm{~mm}$ before the test, decreased to $0.15 \mathrm{~mm}$ (Fig. 3c) in the tensile test, and to $0.12 \mathrm{~mm}$ (Fig. 4) in the QS-PST result. This gives information about the ductility of the material. Further thinning of the material as a result of the QS-PST is due to the fact that the material is not only subjected to tension but also to compression during testing. Thus, the shear stress during the test increased to $550.6 \mathrm{MPa}$ in analytical calculations given above (when the material thickness was kept constant), while as a result of this thinning, it increased to $656.0 \mathrm{MPa}$ in the FEA (because the area 'A' became smaller).

During the analysis, the thickness of the material decreased due to the deformation, and the shear stress increased because the area on which the shear force was applied decreased. The FEA results are given below both visually (Fig. 5) and graphically (Fig. 6). In terms of comparison, when the experimental and numerical images after QS-PST are examined, the behavior and deformation areas of the material under loading show great similarity (Fig. 4-Fig. 5b).

In Fig. 5a, a numerical analysis image of the entire system after the test is given, while in Fig. 5b, the mesh structure of the workpiece after fracture is illustrated in detail. Thanks to the re-meshing feature pf the software during the FEA, the mesh size has been increased in areas with excessive stress by reducing the mesh structure. As a result of this, the results converged to the experimental results as more precise calculations were made. In Fig. $5 \mathrm{c}$, the damage of the workpiece after breakage is shown, and the result with a value above 1 on the surfaces with separation confirms the analysis. In Fig. 5d, the effective strain results that occur in the workpiece during the test are shown. In Fig. 5e and Fig. 5f, the maximum shear stresses are given when the punch moves $4 \mathrm{~mm}$ and 5.31 $\mathrm{mm}$ (at the moment of fracture), respectively. As can be seen here, during the test, the maximum shear stress occurred around the surface where the punch contacts the workpiece, and as a result, separation occurred here.

When the numerical study results are compared with the experimental results, it is seen that there is a close similarity in both visual deformation and numerical results. The main reason for this is related to correctly defining the parameters such as friction, mesh structure, number of mesh and simulation steps during FEA. The effect of the number of mesh, which is one of the most important of these parameters, on the results has been examined in this study, and the force-deformation graph of the mesh number starting from 16700 to 151800 is given (Fig. 6a).
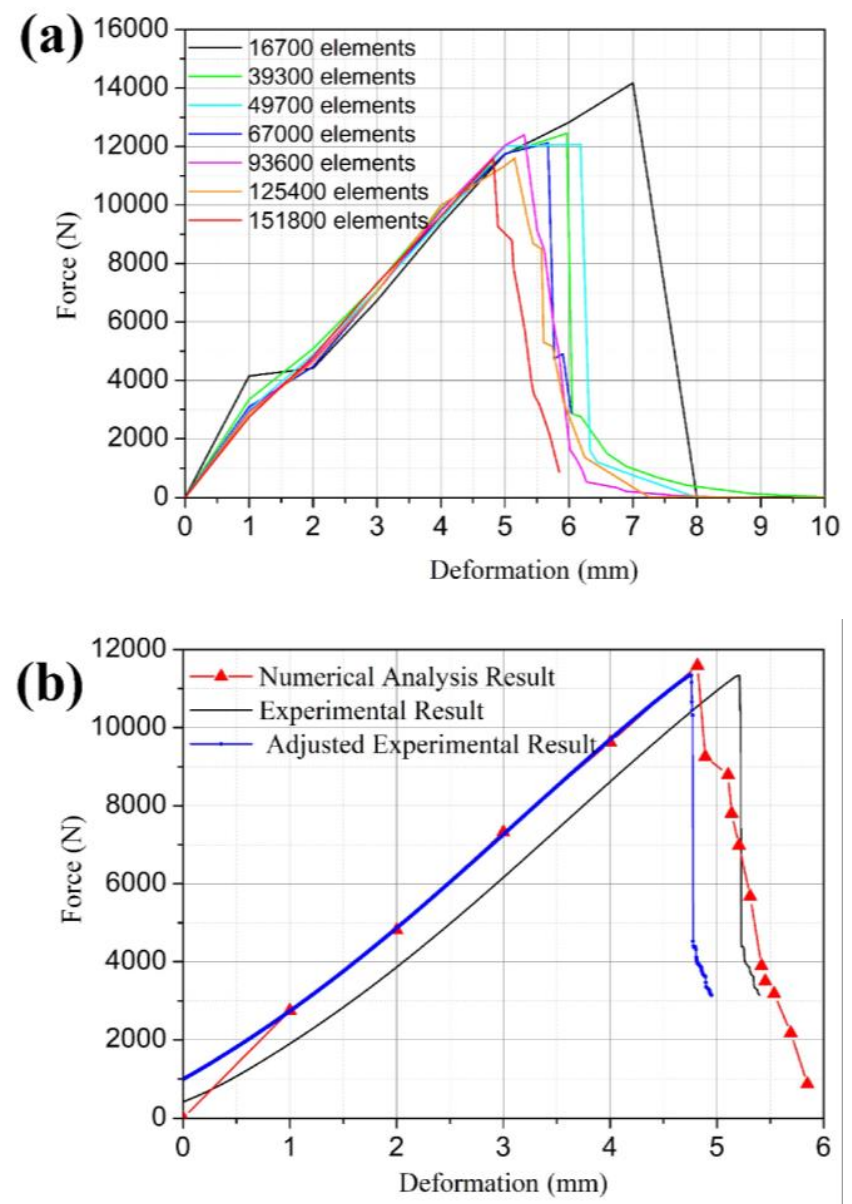

Figure 6. QS-PST Force-Strain graphs (a) numerical analysis result with different element numbers (b) numerical and experimental comparison

Then, these graphs were compared with the experimental force-shape change graph, this situation is shown in Fig. $6 \mathrm{~b}$ and some values are also given as a table (Table 1).

It has been determined that the closest numerical solution to the experimental graph is the analysis with 151800 mesh, and in Fig. 6b it is given comparatively. As can be seen in the graph, the deformation caused by the stretching of the experimental workpiece is somewhat offset. This situation, which seems to be a shape change difference between experimental and numerical, has been resolved with the experimental adjusted graph. While generating the experimentally adjusted graph, the graph was shifted $45 \mathrm{~mm}$ to the left (in the strain axis) without changing the force values, and overlapped with the experimental. This is clearly seen from the values in Table 1.

As can be seen from Table 1, the values for maximum force $(\mathrm{N})$ and maximum strain $(\mathrm{mm})$ after QS-PST are given for all numerical analyses, experimental raw and adjusted experimental procedures. In the table, the numerical analysis results were compared with the 
experimental (adjusted) results and it was seen that the smallest difference in both maximum force and maximum deformation was with the analysis with a mesh number of 151800 .

Table 1. Comparison of Numerical Analysis results with experimental

\begin{tabular}{lcccc}
\hline Number of Elements & Max. Force (N) & $\begin{array}{c}\text { Experimental } \\
\text { Difference (\%) }\end{array}$ & $\begin{array}{c}\text { Maximum Deformation } \\
(\mathrm{mm})\end{array}$ & $\begin{array}{c}\text { Experimental (adjusted) } \\
\text { Difference (\%) }\end{array}$ \\
\hline 16700 & 14172.44 & 24.93 & 7.00 & 47.05 \\
39300 & 12452.67 & 9.77 & 5.96 & 25.21 \\
49700 & 12066.93 & 6.37 & 6.18 & 29.83 \\
67000 & 12120.00 & 6.84 & 5.67 & 19.12 \\
93600 & 12400.24 & 9.31 & 5.30 & 11.34 \\
125400 & 11600.26 & 2.26 & 5.15 & 8.19 \\
151800 & 11586.98 & 2.14 & 4.82 & 9.26 \\
\hline Experimental Raw & 11343.99 & 0 & 5.21 & 9.45 \\
Experimental & 11343.99 & 0 & 4.76 & 0 \\
Adjusted & & & & \\
\hline
\end{tabular}

\section{CONCLUSION}

In this study, QS-PST was applied both experimentally and numerically for 304 SS then the results were compared. When the mesh size is thinned, a numerical model very close to the experiment is obtained. The same stainless steel sheet material and experimental setup used in the experiment were prepared for the numerical model. After that, a FEAs was carried out by assigning different mesh numbers to the workpiece. When the analysis with the highest number of meshes with 151800 elements is compared with the experimental results;

- A $2.14 \%$ difference in the maximum forces applied by the punch is detected,

- A $1.26 \%$ difference was observed in the maximum deformation of the material.

These very low differences are acceptable for numerical studies, and a model that is very close to reality has been obtained with this study. In future studies, this model can be examined on parameters such as material thickness, material layer number, punch-hole ratio.

In addition, as a result of the numerical analysis of this model, the damage, effective stress and effective strain values were examined and it was seen that the highest values were found in the parts of the material with tearing, as expected. This situation confirms each other with the optical microscope images, and it is seen that the thickness of this material, which has a very high ductility, decreased by about 4 times in the tear region and decreased to $0.12 \mathrm{~mm}$.

\section{ACKNOWLEDGEMENT}

I would like to thank KMU Mechanical Engineering Department Head Prof. Dr. Uğur Köklü and his management team for the laboratory facilities. I would like to thank Dr. Ali İmran Ayten for mold supply and Dr. Bekir Güney and Teach. Asst. Hüseyin Kaya for material supply. I would like to thank the editors and referees for their contributions during the review and evaluation process of the article.

\section{Conflicts of interest}

The author declares no conflicts of interest.

\section{REFERENCES}

Al-Bakri A A, Sajuri Z, Ariffin A K, Razzaq M A \& Fafmin M $S$ (2016). Tensile and fracture behaviour of very thin 304 stainless steel sheet. Jurnal Teknologi, 78(6-9), 45-50. doi: 10.11113/jt.v78.9146

Aydın K \& Karaağaç İ (2019). DP600 ve HSLA300 Sac Malzemelerde Geri Esneme Davranışlarına Proses Parametrelerinin Etkisinin Deneysel Araștırılması. Düzce Üniversitesi Bilim ve Teknoloji Dergisi, 7(3), 1456-1465. doi: 10.29130/dubited.532628

Ayten A İ, Ekici B \& Taşdelen M A (2020). A numerical and experimental investigation on quasi-static punch shear test behavior of aramid/epoxy composites. Polymers and Polymer Composites, 28(6), 398-409. doi: 10.1177/0967391119881554

Çağdaş I U \& Taşkın M (2020). A modified analytical expression to determine the quasi-static preindentation loads of metal-faced sandwich beams. Journal of Sandwich Structures \& Materials, 22(5), 1404-1425. doi: 10.1177/1099636218785829

Çeliker S, Eşsiz E S \& Oturakcı M (2021). Integrated AHPFMEA risk assessment method to stainless tank production process. Turkish Journal of Engineering, 5(3), 118-122. doi:10.31127/TUJE.702369

Emirler B, Tolun M \& Yıldız A (2019). Eğik Çekme Yükü Etkisindeki Tekil Kazığın Üç Boyutlu Sayısal Analizi. Çukurova University Journal of the Faculty of Engineering and Architecture 34(2), 219-229. doi: 10.21605/cukurovaummfd.609235

Hasçelik A \& Aslantaş K (2021). Mikro tornalama işleminde kesme kuvveti katsayılarının mekanistik ve nümerik modelleme ile tespiti. Gazi Üniversitesi Mühendislik Mimarlık Fakültesi Dergisi.; 37(1): 235246. doi:10.17341/gazimmfd.794462

Kaoumi D \& Liu J (2018). Deformation induced martensitic transformation in 304 austenitic stainless steel: In-situ vs. ex-situ transmission electron microscopy characterization. Materials Science and Engineering A, 715, 73-82. doi: 10.1016/j.msea.2017.12.036 
Karajibani E, Hashemi R \& Sedighi M (2017). Forming limit diagram of aluminum-copper two-layer sheets: numerical simulations and experimental verifications. International Journal of Advanced Manufacturing Technology, 90(9-12), 2713-2722. doi: $10.1007 / s 00170-016-9585-1$

Kawano S, Kaminishi K, Yamashita M \& Shimizu S (1988). Energy-absorbing capacity of ductile thin metal sheet under quasi-statical penetration by conical punch. JSME Int J Ser 1, 31(1), 108-116. doi: 10.1299/jsmea1988.31.1_108

Köleoğlu Gürsoy Ö \& Esener E (2019). Malzeme Modellerinin Sac Metal Sonlu Elemanlar Analizi Tahmin Performansına Etkisinin Değerlendirilmesi. Bilecik Şeyh Edebali Üniversitesi Fen Bilimleri Dergisi, 6(1). doi: 10.35193/bseufbd.549657

Longère P \& Dragon A (2015). Dynamic vs. quasi-static shear failure of high strength metallic alloys: Experimental issues. Mechanics of Materials, 80(PB), 203-218. doi: 10.1016/j.mechmat.2014.05.001

Ögüt S, Kaya H, Kentli A \& Uçar M (2021). Applying hybrid equal channel angular pressing (HECAP) to pure copper using optimized Exp.-ECAP die. International Journal of Advanced Manufacturing Technology, 116(11-12), 3859-3876. doi:10.1007/s00170-021-07717-9

Salman S D, Leman Z, Ishak M R, Sultan M T H \& Cardona F (2018). Quasi-static penetration behavior of plain woven kenaf/aramid reinforced polyvinyl butyral hybrid laminates. Journal of Industrial Textiles, 47(7), 1427-1446. doi:10.1177/1528083717692593

Seyedzavvar M, Seyedzavvar M, Olıae S N B \& Abbasi H (2022). Numerical simulation and experimental investigation: Metal spinning process of stepped thinwalled cylindrical workpiece. Turkish Journal of Engineering, 6(1), 67-80. doi:10.31127/TUJE.824890
Şahbaz M, Kentli A, Yilmaz M, Köten H \& Yükselentürk Y (2013). Modeling and Thermal Analysis of High Power Led Armature. International Symposium on Computing in Science \& Engineering. Proceedings, 164-168.

Şahbaz M, Öğüt S \& Kentli A (2016). Cadde Tipi Led Armatürün Isı Yayıcısında SEY ve YSA Modeli Kullanılarak Sıcaklık Tahmini Yapılması. Marmara Fen Bilimleri Dergisi, 28(2). doi: 10.7240/mufbed.09519

Şahbaz M, Kaya H, Kentli A, Uçar M, Öğüt S \& Özbeyaz K (2019). Analytical and Numerical Analysis Comparison of Equal Channel Angular Pressing for Al5083 Alloy. Advanced Science, Engineering and Medicine, 11(11), 1100-1103. doi:10.1166/asem.2019.2461

Şener B, Kılıçaslan E S \& Firat M (2020). Modelling anisotropic behavior of AISI 304 stainless steel sheet using a fourth-order polynomial yield function. Procedia Manufacturing, 47, 1456-1461. Elsevier B.V. doi: 10.1016/j.promfg.2020.04.320

Türkoğlu T \& Ay I (2021). Investigation of mechanical, kinetic and corrosion properties of borided AISI 304, AISI 420 and AISI 430. Surface Engineering. doi: 10.1080/02670844.2021.1884332

Uçtu Ö, Sevim İ, Karataş B \& Şahin B (2017). Determination of optimum mesh size to measure tooth root stress of spur gear using finite element analysis. Turkish Journal of Engineering, 1(1), 37-43. doi:10.31127/TUJE.320047

Vatansever H \& Esener E (2019). Sonlu Elemanlar Hesaplama Parametrelerinin Sac Metal Șekillendirme Simülasyon Süresi ve Hassasiyetine Etkisinin Tespiti. European Journal of Science and Technology, 16, 92108 doi: 10.31590/ejosat.555491 